\title{
The role of thiol/disulfide homeostasis in psoriasis: Can it be a new marker for inflammation?
}

\author{
Psoriazis vulgarisli hastalarda tiyol/disülfit homeostazının rolü: Yeni bir enflamatuvar \\ belirteç olabilir mi?
}

\section{Pelin Üstüner, ๑ Ali Balevi, ๑ Mustafa Özdemir, ๑ Oktay Olmușçelik*, ๑ Gözde Ülfer**, ๑ Türkan Yiğitbași**}

İstanbul Medipol University Faculty of Medicine, Department of Dermatology; *Department of Internal Medicine; **Department of Biochemistry, İstanbul, Turkey

\begin{abstract}
Background and Design: Psoriasis vulgaris is a chronic, systemic, inflammatory disease presenting with oxidative stress and tissue inflammation. Thiol and disulfide levels have been shown to increase in inflammatory diseases as a marker of total oxidant status. To date, imbalances or abnormalities in thiol/disulfide homeostasis have been shown to have an etiopathogenetic role in a few dermatological diseases, such as seborrheic dermatitis, atopic dermatitis, alopecia areata, acute urticaria, and melasma. We aimed to investigate whether blood thiol and disulfide levels or thiol/disulfide ratios are increased in psoriasis vulgaris and to determine whether they can be used as a novel prognostic inflammatory marker.

Materials and Methods: The blood levels of native thiol, total thiol and disulfide were analyzed in a total of 29 patients diagnosed with psoriasis vulgaris by biopsy and 30 healthy controls. Native-total thiol, disulfide-native thiol and disulfide-total thiol ratios were compared between the two groups. The correlation between these measurements and Psoriasis Area and Severity Index (PASI) values were also examined in patients with psoriasis.

Results: The disulfide levels were higher in patients with psoriasis vulgaris compared to the control group $(p=0.021 ; p<0.05)$, however, the levels of native thiol and total thiol as well as the ratios of disulfide/native thiol and disulfide/total thiol were similar in both groups ( $p>0.05)$. PASI scores were not significantly correlated with the levels of total and native thiol and disulfide/native thiol and disulfide/total thiol ratios $(\mathrm{p}>0.05)$.

Conclusion: The increase in blood disulfide levels indicating a thiol/disulfide imbalance was significant in psoriasis vulgaris as a result of oxidative stress and tissue inflammation. However, the level of disulfide did not show a definite positive correlation with the severity of psoriasis measured using PASI.

Keywords: Homeostasis, oxidative stress, peroxiredoxins, psoriasis, sulfhydryl compounds

Öz

Amaç: Psoriazis vulgaris oksidatif stres ve dokuda enflamasyon ile seyreden kronik, sistemik enflamatuvar bir hastalıktır. Tiyol ve disülfit seviyelerinin total oksidan durumun bir belirteci olarak enflamatuvar hastalıklarda arttı̆̆ı gösterilmiștir. Bugüne kadar, seboreik dermatit, atopik dermatit, alopesi areata, akut ürtiker ve melasma gibi birçok dermatolojik hastalıkta tiyol/disülfit homeostazındaki dengesizlik ya da anormalliklerin etiyopatogenetik rolü olduğu gösterilmiştir. Psoriazis vulgariste tiyol ve disülfit kan seviyelerinin ya da tiyol/disülfit oranlarının artışını araştırmak ve yeni prognostik enflamatuvar belirteç olarak kullanılabilirliğini belirlemeyi amaçladık.

Gereç ve Yöntem: Biyopsi ile tanı almış 29 psoriazis hastasındaki ve 30 sağlıklı kontrol grubunda natif tiyol, total tiyol ve disülfit kan seviyeleri araştırıldı. Natif-total tiyol, disülfit-natif tiyol ve disülfit-total tiyol oranları iki grup arasında karşılaştırılı. Psoriazisli hastalarda bu ölçümler ve Psoriazis Alan ve Şiddet İndeks (PAŞi) değerleri arasındaki korelasyonda incelendi.
\end{abstract}

Address for Correspondence/Yazışma Adresi: Pelin Üstüner MD, İstanbul Medipol University Faculty of Medicine, Department of Dermatology, İstanbul, Turkey Phone: +90 5052520223 E-mail: pelindogaustuner@gmail.com Received/Geliş Tarihi: 24.10.2017 Accepted/Kabul Tarihi: 27.04.2018 ORCID ID: orcid.org/0000-0002-7885-0537

(C) Copyright 2018 by Turkish Society of Dermatology and Venereology

Turkderm-Turkish Archives of Dermatology and Venereology published by Galenos Yayınevi. 
Bulgular: Psoriazisli hastalarda kontrol grubuna oranla disülfit seviyeleri daha yüksekti $(p=0,021 ; p<0,05)$; ancak, natif tiyol ve total tiyol seviyeleri benzerdi, ayrıca disülfit/natif tiyol ve disülfit/total tiyol oranları da her iki grupta benzerdi $(p>0,05)$. PAşi değerleri ile total tiyol, natif tiyol ölçümleri, disülfit/natif tiyol ve disülfit/total tiyol oranları arasında anlamlı korelasyon saptanmadı $(p>0,05)$.

Sonuç: Oksidatif stres ve doku enflamasyonunun bir sonucu olarak psoriazisde tiyol/disülfit dengesizliğini gösteren kan disülfit seviyelerindeki artış anlamlı bulundu. Ancak, disülfit miktarı PAŞi kullanılarak ölçülen psoriazis şiddeti ile kesin pozitif bir korelasyon göstermemekteydi.

Anahtar Kelimeler: Homeostaz, oksidatif stres, peroksiredoksinler, psoriazis, sülfidril bileşikleri

\section{Introduction}

Oxidative stress causes profound alterations of various biological structures, including cellular membranes, lipids, proteins, and nucleic acids ${ }^{1}$. It has been shown that as oxidative stress increases in inflammatory diseases via the enzymatic activities of thiol/disulfide oxidoreductases in the presence of glutathione $(\mathrm{GSH})$, proteindisulfide is reduced to a protein dithiol ${ }^{1}$. After the production of these oxygen free radicals as a result of total oxidant capacity, thiol/disulfide homeostasis (TDHS) status becomes imbalanced ${ }^{2}$. Thiol is a sulfurcontaining antioxidant compound that has a negative correlation with oxidative stress ${ }^{3}$. Oxidant radicals form disulfide bonds by oxidizing the thiol groups that are present in the side chains of sulfur-containing amino acids of proteins ${ }^{1}$.

Recent studies have implicated the association between oxidative stress and inflammation in the pathogenesis of comorbidities associated with psoriasis ${ }^{48}$. Psoriasis vulgaris is a chronic, remitting and relapsing inflammatory skin disease developing as a result of immune dysregulation, mostly associated with impaired suppressive function of T regulatory cells (Tregs), which causes enhancement of $\mathrm{T}_{\mathrm{h}}-17^{9}$. This immune imbalance may also cause overproduction of reactive oxygen species (ROS) and such oxidants or lack of certain antioxidants ${ }^{4,5}$. TDHS is known to have a critical role in many cellular activities, such as antioxidant protection, detoxification, cell growth and apoptosis 1,2 . TDHS has been reported to play an essential role in immunopathogenesis of oxidation reactions. If this TDHS is imbalanced, it is believed to trigger autoimmune diseases by causing oxidative stress and tissue inflammation ${ }^{1,2}$. The etiopathological role of TDHS has previously been investigated in various diseases and conditions, including prediabetes, autoimmune subclinical hypothyroidism due to Hashimoto thyroiditis, Polycystic ovary syndrome, Crimean-Congo hemorrhagic fever, sudden sensorineural hearing loss, and premature ovarian failure ${ }^{10-13}$. In another study, the sulfhydryl (SH) and disulfide concentrations in psoriatic scales were examined and various methods were used to quantitatively determine and evaluate $\mathrm{SH}$ and disulfide (S-S) bonds ${ }^{14}$. The authors analyzed specimens from 5 patients with psoriasis by amperometric titration and a colorimetric method and found the parakeratotic scales of psoriatic patients to have an unusually high $\mathrm{SH}$ concentration.

Cell signaling pathways, such as mitogen-activated protein kinaseactivator protein 1, nuclear factor- $\mathrm{kB}$, and Janus kinase-signal transducers, as well as activators of transcription are redox-sensitive and involved in the progression of psoriasis ${ }^{4}$. Dimethyl fumarate upregulates GSH and $\mathrm{NAD}(\mathrm{P}) \mathrm{H}$ : quinone oxidoreductase 1 and activates the Nrf2 transcriptional pathway, thereby resulting in anti-inflammatory effects, such as downregulation of cytokines and adhesion molecules ${ }^{4,5}$. ROS have been shown to prevent imiquimod-induced psoriatic dermatitis by enhancing Treg cell function ${ }^{7}$. Successful treatment of psoriasis via hyperbaric oxygen therapy and phototherapy can also be attributed to the elevation of ROS levels enhancing Treg function.

To the best of our knowledge, this is the second clinical study to examine the dynamic TDHS in patients diagnosed with psoriasis vulgaris ${ }^{8}$. This study aimed to evaluate the oxidant-antioxidant balance in patients with psoriasis vulgaris by detecting dynamic TDHS, which is a novel oxidative stress marker. Total oxidant status (TOS) and total antioxidant status were also analyzed via the levels of total thiol, native thiol and disulfide, and ratios of disulfide-total thiol and disulfide-native thiol.

\section{Materials and Methods}

The prospective controlled study aimed to compare the dynamic TDHS between patients with psoriasis vulgaris and healthy volunteers aged over 18 years. None of the participants had received any prior treatment within the past six months. A total of 29 patients diagnosed with psoriasis vulgaris by biopsy and 30 healthy controls were recruited from our hospital between June 2016 and January 2017. The study was approved by the İstanbul Medipol University International Faculty of Medicine Clinical Research Ethics Committee approval was obtained (approval number: 378), and all the patients provided written informed consent. Age, gender, systolic and diastolic blood pressure, and body mass index (BMI) values were all recorded. In both the study and control groups, serum creatinine, total protein, albumin, triglyceride, total cholesterol, blood lipid profile, fasting glucose and glycated hemoglobin A1c ( $\mathrm{HbA} 1 \mathrm{c})$ levels were also noted. Patients with known diabetes mellitus, documented cardiovascular and cerebrovascular diseases, acute chronic kidney or liver diseases, nephrotic proteinuria, a history of inflammatory diseases, such as infection or rheumatism and malignity, as well as those using antioxidant substances, lipid lowering substances, drugs, alcohol, vitamins or those who smoked were excluded from the study.

The severity of psoriasis was recorded in the patient group using the Psoriatic Area and Severity Index (PASI) scores. Dynamic TDHS was measured using a novel automated method developed by Erel and Neselioglu' A new, fully automated method was used to measure plasma thiol, total thiol and disulfide levels in both groups.

Blood samples were taken from the participants after eight hours of fasting to evaluate thiol/disulfide levels using a biochemistry tube. The serum samples were centrifuged at $1500 \mathrm{rpm}$ for 10 minutes and then kept at $-80{ }^{\circ} \mathrm{C}$. The reducible disulfide bonds were reduced to form free functional thiol groups. Formaldehyde was used to remove unused and consumed sodium borohydride, and once reaction with DTNB [5,5'-dithiobis - (2-nitrobenzoic acid)] was achieved, all thiol groups, including both reduced and native groups, were determined. 
The amount of dynamic disulfide was determined by taking half of the difference between total thiol and native thiol groups. Following the calculation of native and total thiol and disulfide amounts, the ratios of native thiol/total thiol, disulfide/native thiol and disulfide/total thiol were all determined and compared between patients with psoriasis vulgaris and controls. Furthermore, the clinical association between these values and PASI scores were examined.

\section{Statistical Analysis}

The Number Cruncher Statistical System (NCSS) 2007 (Kaysville, Utah, USA) was used for the statistical analysis. The data was evaluated using statistical methods (mean, standard deviation, median, frequency, ratio, minimum and maximum). The quantitative parameters that did not have a normal distribution in the two groups were compared using the Mann-Whitney $U$ test. For the evaluation of the correlation between the variables, the Spearman's correlation coefficient was determined. The significance was evaluated at $p<0.05$.

\section{Results}

No significant difference was noted in total thiol and native thiol levels between the psoriasis and control groups ( $p>0.05$ ) (Table 1) (Figure 1). However, the blood disulfide level was remarkably higher in the psoriasis group than in the control group $(p=0.021 ; p<0.05)$ (Figure 2$)$. We did not observe any statistically significant difference in the disulfide/native thiol value (\%) ( $p=0.056 ; p>0.05)$, however, it was remarkably higher in the psoriasis group compared to that in the control group (Table 1) (Figure 3). The values of disulfide/total thiol (\%) were also similar in both groups ( $p>0.05$ ) (Figure 3 ).

The mean PASI score in patients with psoriasis was $5.87 \pm 5.27$ with a range of 1.2 and 18.6. No significant correlation was noted between PASI scores and the levels of total thiol, native thiol, and disulfide as well as the ratios of disulfide/native thiol and disulfide/total thiol ( $p>0.05$ ) (Table 2).

\section{Discussion}

Oxidative stress is an imbalance between oxidant and antioxidant systems and plays a major role in the pathogenesis of psoriasis ${ }^{49}$ Increased levels of oxidant radicals stimulate autoimmunity and inflammation. In a previous study, 90 patients with psoriasis who had not received any systemic treatment within the past six months and 76 age- and gender-matched healthy volunteers were compared in terms of $\mathrm{TDHS}^{8}$. Native thiol and total thiol levels were found to be significantly higher in patients with psoriasis than in controls. When the authors compared the TDHS parameters according to clinical and demographic characteristics, they identified a negative correlation between age and

Table 2. The correlation of Psoriasis Area and Severity Index values with total thiol, native thiol and disulfide levels in patients with psoriasis

\begin{tabular}{|c|c|c|}
\hline & & PASI \\
\hline \multirow{2}{*}{ Total thiol } & r & 0.028 \\
\hline & $\mathrm{p}$ & 0.083 \\
\hline \multirow{2}{*}{ Native thiol } & r & 0.024 \\
\hline & $p$ & 0.903 \\
\hline \multirow{2}{*}{$\mu \mathrm{mol}$ total thiol } & r & 0.028 \\
\hline & $p$ & 0.083 \\
\hline \multirow{2}{*}{$\mu \mathrm{mol}$ native thiol } & r & 0.024 \\
\hline & $p$ & 0.903 \\
\hline \multirow{2}{*}{ Disulfide } & $r$ & -0.115 \\
\hline & $p$ & 0.552 \\
\hline \multirow{2}{*}{ Disulfide/native thiol (\%) } & $r$ & -0.108 \\
\hline & $p$ & 0.578 \\
\hline \multirow{2}{*}{ Disulfide/total thiol (\%) } & $r$ & -0.168 \\
\hline & $p$ & 0.383 \\
\hline
\end{tabular}

\section{Table 1. The assessment of total thiol, native thiol and disulfide levels in the psoriasis and control groups}

\begin{tabular}{|c|c|c|c|c|}
\hline & & Psoriasis group $(n=29)$ & Control group $(n=30)$ & p \\
\hline \multirow{2}{*}{ Total thiol } & min-max (Median) & $0.31-0.82(0.43)$ & $0.27-0.72(0.39)$ & \multirow{2}{*}{0.317} \\
\hline & Mean \pm SD & $0.45 \pm 0.14$ & $0.42 \pm 0.11$ & \\
\hline \multirow{2}{*}{ Native thiol } & min-max (Median) & $0.25-0.78(0.38)$ & $0.22-0.6(0.37)$ & \multirow{2}{*}{0.644} \\
\hline & Mean \pm SD & $0.40 \pm 0.13$ & $0.37 \pm 0.08$ & \\
\hline \multirow{2}{*}{$\mu \mathrm{mol}$ total thiol } & min-max (Median) & $309.4-817.7(425.1)$ & $267.8-724.1(390)$ & \multirow{2}{*}{0.317} \\
\hline & Mean \pm SD & $453.61 \pm 138.87$ & $416.82 \pm 108.06$ & \\
\hline \multirow{2}{*}{$\mu \mathrm{mol}$ native thiol } & min-max (Median) & $245.7-782.6(377)$ & $219.7-604.5(365.3)$ & \multirow{2}{*}{0.644} \\
\hline & Meant \pm SD & $402.64 \pm 133.91$ & $372.15 \pm 84.36$ & \\
\hline \multirow{2}{*}{ Disulfide } & min-max (Median) & $8.45-72.15(21.45)$ & $4.55-87.1(16.58)$ & \multirow{2}{*}{0.021 * } \\
\hline & Mean \pm SD & $25.48 \pm 12.78$ & $22.34 \pm 20.77$ & \\
\hline \multirow{2}{*}{ Disulfide/native thiol (\%) } & min-max (Median) & $1.67-12.96(6.33)$ & $1.34-19.36(4.28)$ & \multirow{2}{*}{0.056} \\
\hline & Meant \pm SD & $6.77 \pm 3.17$ & $5.87 \pm 4.65$ & \\
\hline \multirow{2}{*}{ Disulfide/total thiol (\%) } & min-max (Median) & $0.45-10.29(5.61)$ & $1.31-13.96(3.95)$ & \multirow{2}{*}{0.105} \\
\hline & Mean \pm SD & $5.69 \pm 2.60$ & $4.98 \pm 3.40$ & \\
\hline
\end{tabular}




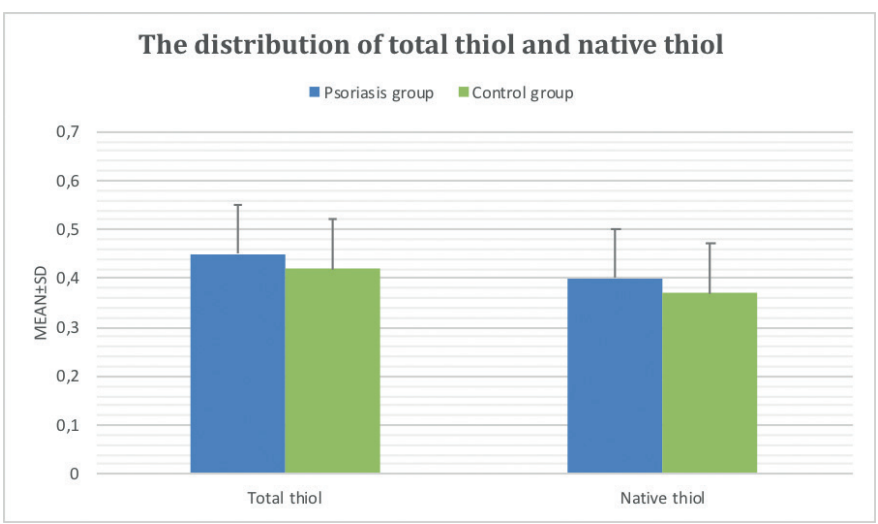

Figure 1. The distribution of total thiol and native thiol levels in the psoriasis and control groups SD: Standard deviation

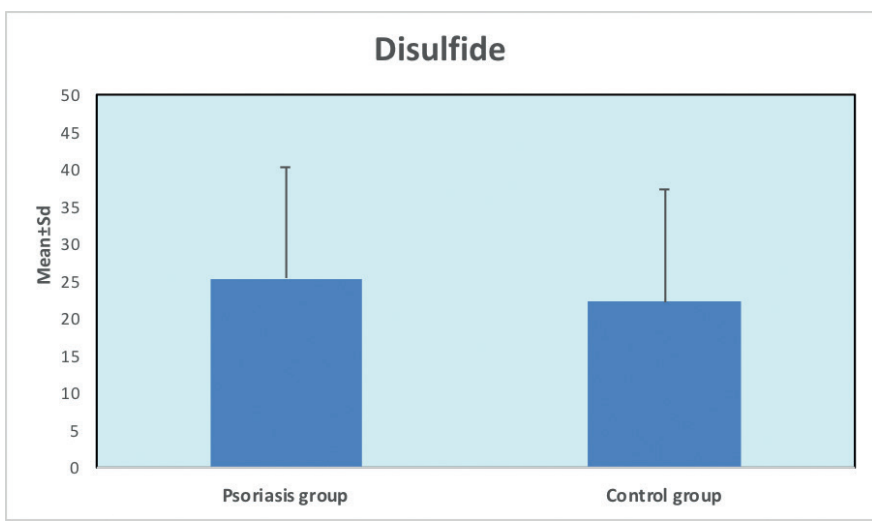

Figure 2. The distribution of disulfide levels in the psoriasis and control groups

SD: Standard deviation

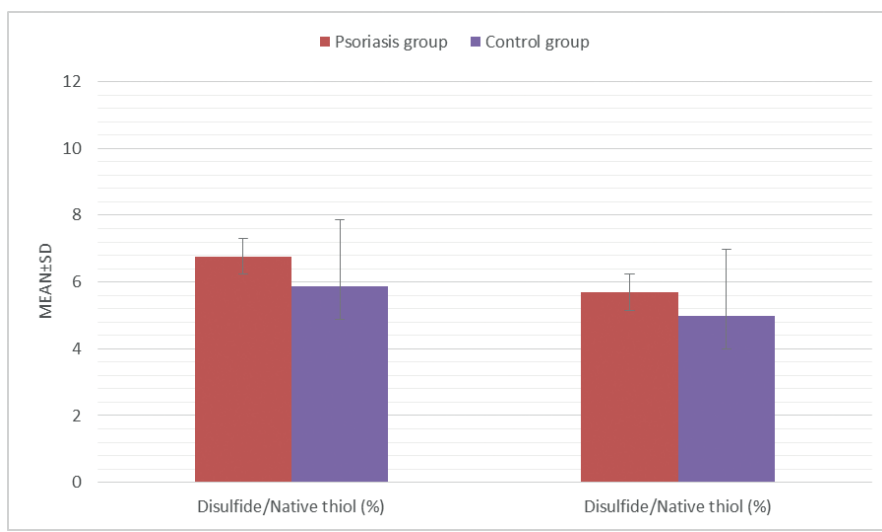

Figure 3. The distribution of disulfide/total thiol and disulfide/native thiol levels in the psoriasis and control groups

SD: Standard deviation

the levels of native and total thiol. In the current study, the levels of total thiols had a negative correlation with PASI and the duration of the disease. On the other hand, the absence of a positive correlation between PASI and TDHS in our study indicates that in addition to oxidative stress, several other factors including genetic, diet and environment can play a role in the pathogenesis of psoriasis vulgaris. Psoriasis vulgaris is also a systemic, inflammatory, T cell-mediated skin disease with increased oxidative stress mostly accompanied with chronic inflammatory diseases, such as atherosclerosis, metabolic syndrome, diabetes mellitus, hypertension, and hyperlipidemia ${ }^{15}$. Therefore, we believe that exclusion of patients with a known history of diabetes mellitus, cardiovascular and cerebrovascular diseases, acute chronic kidney or liver diseases, nephrotic proteinuria or a history of inflammatory disease was essential to investigate the effect of only psoriasis by minimizing the effect of other factors. The increased epidermal turnover seen in epidermal corneocytes presenting with abnormal desquamation may cause a protein loss that results in lower total and native thiol levels in psoriasis. However, we found the native or total thiol levels to be similar in both the psoriasis and control groups. Moreover, in certain inflammatory diseases, such as insulin resistance or pre-diabetes mellitus, disulfide level and disulfide/native thiol or disulfide/total thiol ratios have been shown to be higher and have a positive correlation with fasting blood sugar and $\mathrm{HbA} 1 \mathrm{C}$ as a result of the oxidation process ${ }^{10}$. In prediabetic patients, the main reason for the decrease in native thiol and increase in disulfide has been suggested to be loss of urinary abnormal thiol protein ${ }^{10}$. The positive correlation between total protein and native thiol supports this fact. The significantly higher level of disulfide in the psoriasis patients in our study was remarkable and similar to the results reported by a previous TDHS study on prediabetes mellitus ${ }^{10}$. Aging is another factor affecting oxidative stress and resulting in lower thiol and higher disulfide levels ${ }^{16}$. We also believe that assessment of TDHS in patients with psoriasis in terms of BMI would provide valuable data as thiol levels were found to be higher in obesity in a previous report ${ }^{11}$.

Contrary to the case in ROS, the level of some other antioxidant molecules, such as GSH, decreases ${ }^{1,17}$. On the other hand, the level of oxidized GSH (GSSG) increases. Cysteine, cysteinylglycine, GSH, homocysteine, and $\boldsymbol{\gamma}$-glutamylcysteine are some of the amino acids or essential elements containing only lower molecular weight thiols that contain only a small percent of the total body thiol content ${ }^{18}$. GSH is a small protein molecule composed of three amino acids: cysteine, glutamate, and glycine, and it is involved in many processes in the body, including tissue building and repair as well as making chemicals and proteins needed for the body and the immune system ${ }^{19}$. It scavenges free radicals, enhances the immune system, regulates cell division and growth, transports amino acids, and synthesizes and repairs DNA ${ }^{19}$. GSH is considered to be one of the most important scavengers of ROS and the ratio of GSH to GSSG may be used as a marker of anti-oxidative capacity ${ }^{20}$.

Furthermore, it has been shown that impaired GSH/GSSG ratio was related with elevated levels of homocysteine, a marker of endothelial dysfunction and moderate hyperglycemia ${ }^{21}$. It has also been reported that in psoriasis vulgaris, there is a significant increase in the expressions of two antioxidant systems, the GSH S-transferases and cytochrome in the tissue. The former decreases oxidative stress by reducing oxidative products and the latter is a family of enzymes responsible for the metabolism of various endogenous and exogenous substances; e.g., drug metabolism²2.

An increase in super oxide dismutase (SOD) activity has also been described in other chronic inflammatory skin conditions, such as atopic dermatitis and psoriasi ${ }^{23,24}$. The upregulation of SOD gene expression in chronic idiopathic urticaria may represent a defense mechanism against the reactive ROS generated by the respiratory chain complexes ${ }^{25}$. It is 
likely that the overexpression of SOD results from an increased secretion of cytokines, as previously reported in psoriasis ${ }^{23}$. However, as the overproduction of ROS and oxidative burden continues, the antioxidant enzyme defense system may also be damaged and the level of GSHperoxidase (Px), the enzyme responsible for the conversion of GSH to GSH-disulfide, decreases ${ }^{24}$. In another study, SOD and GSH-Px enzyme activities and the levels of malondialdehyde, nitric oxide and protein carbonyl were measured both in patients with melasma and controls. SOD and GSH-Px enzyme activities were reported to be significantly higher in the patient group compared to the control group ${ }^{26}$.

Another issue that needs to be clarified is whether the increase in disulfide levels is a laboratory result of oxidative stress or the elevated disulfide levels cause tissue inflammation. We think that the lack of the evaluation of the oxidant-antioxidant balance in patients with psoriasis vulgaris by detecting dynamic TDHS, which is a novel oxidative stress marker, as well as other molecules, including paraoxonase, arylesterase, ceruloplasmin, myeloperoxidase, the GSH-Px enzyme, and catalase was the limitation of this study. In addition, analysis of the serum levels of certain molecules containing sulfur formed after the oxidation of thiol groups; e.g., cysteine, cysteinylglycine, GSH, homocysteine, and $\boldsymbol{\gamma}$-glutamylcysteine could provide further scientific data about TDHS imbalance in the etiopathogenesis of psoriasis. For future research, we recommend investigating the correlation of TDHS with the duration, clinical type and severity of psoriasis, and previous history of systemic medications, such as methotrexate, cyclosporine and acitretin, or biological agents to provide complementary data about the immunological etiopathogenesis of psoriasis vulgaris. In addition, a greater number of patients are needed to enlighten the role of oxidant and antioxidant systems and other possible mechanisms in the pathogenesis of psoriasis.

We believe that assessment of TDHS in patients with psoriasis in terms of BMI would provide valuable data as thiol levels were found to be higher in gestational diabetes mellitus and maternal obesity in a previous report ${ }^{27}$. Analysis of serum levels of certain molecules containing sulfur formed after the oxidation of thiol groups, such as cysteine, cysteinylglycine, GSH, homocysteine, and $\boldsymbol{\gamma}$-glutamylcysteine could provide further scientific data about TDHS imbalance in the etiopathogenesis of psoriasis. It would also be better to evaluate oxidant-antioxidant balance in patients with psoriasis vulgaris by investigation of some other molecules and antioxidant enzymes including paraoxonase, arylesterase, ceruloplasmin, myeloperoxidase, GSH-Px enzyme and catalase.

For future research, investigating the correlation between the duration, clinical type, severity of psoriasis and previous history of systemic medications, such as methotrexate, cyclosporine and acitretin, or biological agents with TDHS will provide complementary data about the immunological etiopathogenesis of psoriasis vulgaris. We recommend conducting further clinical studies with psoriasis patients to investigate the effect of cysteine-containing supplements on the severity of the disease. New treatment alternatives targeting oxidative stress may also be effective in psoriasis vulgaris. In addition, a greater number of patients are needed to enlighten the role of oxidant and antioxidant systems and the other possible mechanisms for the pathogenesis of psoriasis.

\section{Study Limitation}

The limited number of the patients in our study was the limitation of our study.

\section{Conclusion}

This is the second study in the literature evaluating dynamic TDHS in psoriasis vulgaris. Our findings point to the possible role of oxidative stress in the etiopathogenesis of psoriasis. TDHS status is shifted towards the oxidative side in patients with psoriasis vulgaris, leading to an increase in TOS, which may, in turn, act as an immunological trigger. In the current study, the TDHS shift towards disulfide in patients with psoriasis may be a result of increased keratinocyte proliferation in the pathogenesis of psoriasis. Patients with psoriasis should be encouraged to start an antioxidant therapy or cysteine-rich food intake to regain the antioxidant status. It would be beneficial to conduct further clinical studies with psoriasis patients to investigate the effect of cysteinecontaining supplements on the severity of the disease. New treatment alternatives targeting oxidative stress may also be effective in psoriasis vulgaris.

\section{Ethics}

Ethics Committee Approval: İstanbul Medipol University International Faculty of Medicine Clinical Research Ethics Committee (approval number: 378).

Informed Consent: Informed consent form was obtained from the patient.

Peer-review: Externally peer-reviewed.

\section{Authorship Contributions}

Surgical and Medical Practices: P.Ü., Concept: P.Ü., Design: P.Ü., A.B., O.O., G.Ü., Data Collection or Processing: P.Ü., A.B., O.O., G.Ü., Analysis or Interpretation: P.Ü., A.B., M.Ö., O.O., G.Ü., T.Y., Literature Search: P.Ü., Writing: P.Ü

Conflict of Interest: No conflict of interest was declared by the authors.

Financial Disclosure: The authors declared that this study received no financial support.

\section{References}

1. Erel O, Neselioglu S: A novel and automated assay for thiol/disulphide homeostasis. Clin Biochem 2014;47:326-32.

2. Jones DP, Liang L: Measuring the poise of thiol/disulfide couples in vivo. Free Radic Biol Med 2009:47:1329-38.

3. Sen CK, Packer L: Thiol homeostasis and supplements in physical exercise Am J Clin Nutr 2000;72:653-69.

4. Zhou Q, Mrowietz U, Rostami-Yazdi M: Oxidative stress in the pathogenesis of psoriasis. Free Radic Biol Med 2009;47:891-905

5. Baek J, Lee MG: Oxidative stress and antioxidant strategies in dermatology. Redox Rep 2016;21:164-9.

6. Lin X, Huang T: Oxidative stress in psoriasis and potential therapeutic use of antioxidants. Free Radic Res 2016;50:585-95.

7. Kim HR, Lee A, Choi EJ, et al: Reactive oxygen species prevent imiquimodinduced psoriatic dermatitis through enhancing regulatory $T$ cell function. PLoS One 2014;9:91146.

8. Emre S, Demirseren DD, Alisik M, Aktas A, Neselioglu S, Erel O: Dynamic thiol/disulfide homeostasis and effects of smoking on homeostasis parameters in patients with psoriasis. Cutan Ocul Toxicol 2017;36:393-6.

9. Lowes MA, Kikuchi T, Fuentes-Duculan J, et al: Psoriasis vulgaris lesions contain discrete populations of Th1 and Th17 T cells. J Invest Dermatol 2008;128:1207-11. 
10. Ates I, Kaplan M, Inan B, et al: How does thiol/disulfide homeostasis change in prediabetic patients? Diabetes Res Clin Pract 2015;110:166-71.

11. Ates I, Altay M, Yilmaz FM, et al: Dynamic thiol/disulfide homeostasis in patients with autoimmune subclinical hypothyroidism. Endocr Res 2016;41:343-9.

12. Tufan ZK, Hasanoglu I, Kolgelier S, et al: A retrospective controlled study of thiol disulfide homeostasis as a novel marker in Crimean Congo hemorrhagic fever. Redox Rep 2017;22:241-5.

13. Isik H, Sahbaz A, Timur H, et al: The use of thiol/disulfide as a novel marker in premature ovarian failure. Gynecol Obstet Invest 2017;82:113-8.

14. Ogura R, Knox JM, Griffin AC: An evaluation of methods for determining the sulfhydryl and disulfide concentration in the stratum corneum. J Invest Dermatol 1960;35:125-9.

15. Usta M, Turan E, Aral H, Inal BB, Gurel MS, Guvenen G: Serum paraoxonase-1 activities and oxidative status in patients with plaque-type psoriasis with/ without metabolic syndrome. J Clin Lab Anal 2011;25:289-95.

16. Pansarasa O, Bertorelli L, Vecchiet J, Felzani G, Marzatico F: Age-dependent changes of antioxidant activities and markers of free radical damage in human skeletal muscle. Free Radic Biol Med 1999;27:617-22.

17. Głowacki R, Bald E: Fully automated method for simultaneous determination of total cysteine, cysteinylglycine, glutathione and homocysteine in plasma by HPLC with UV absorbance detection. J Chromatogr B Analyt Techno Biomed Life Sci 2009;877:3400-4.

18. Turell L, Radi R, Alvarez B: The thiol pool in human plasma: the central contribution of albumin to redox processes. Free Radic Biol Med 2013:65:244-53.

19. Lu SC: Regulation of glutathione synthesis. Mol Aspects Med 2009;30:42 59
20. Zitka O, Skalickova S, Gumulec J, et al: Redox status expressed as GSH: GSSG ratio as a marker for oxidative stress in paediatric tumour patients. Oncol Lett 2012:4:1247-53.

21. Maschirow L, Khalaf K, Al-Aubaidy HA, Jelinek HF: Inflammation, coagulation, endothelial dysfunction and oxidative stress in prediabetesBiomarkers as a possible tool for early disease detection for rural screening. Clin Biochem 2015;48:581-5.

22. Akbulak O, Karadag AS, Akdeniz N, et al: Evaluation of oxidative stress via protein expression of glutathione S-transferase and cytochrome p450 (CYP450) isoenzymes in psoriasis vulgaris patients treated with methotrexate. Cutan Ocul Toxicol 2018;37:181-5.

23. Löntz W, Sirsjö A, Liu W, Lindberg M, Rollman O, Törmä H: Increased mRNA expression of manganese superoxide dismutase in psoriasis skin lesions and in cultured human keratinocytes exposed to IL-1 beta and TNF-alpha. Free Radic Biol Med 1995;18:349-55.

24. Fuchs J: Oxidative injury in dermatopathology. Berlin. Springer, 1992.

25. Kalkan G, Seçkin HY, Duygu F, Akbaş A, Ozyurt H, Sahin M: Oxidative stress status in patients with acute urticaria. Cutan Ocul Toxicol 2014;33:109-14.

26. Seçkin HY, Kalkan G, Baş Y, Akbaş A, Önder Y, Özyurt H, Sahin M: Oxidative stress status in patients with melasma. Cutan Ocul Toxicol 2014;33:212-7.

27. Ozler S, Oztas E, Erel O, Guler BG, Ergin M, Uygur D, et al.: Impact of Gestational Diabetes Mellitus and Maternal Obesity on Cord Blood Dynamic Thiol/Disulfide Homeostasis. Fetal Pediatr Pathol 2017;36:8-15. 